\title{
Retraction Note to: Simple Sequence Repeat and S-locus Genotyping to Explore Genetic Variability in Polyploid Prunus spinos $a$ and $P$. insititia
}

\author{
Júlia Halász ${ }^{1}$ (D) Noémi Makovics-Zsohár ${ }^{1} \cdot$ Ferenc Szőke $^{2} \cdot$ Sezai Ercisli $^{3}$. \\ Attila Hegedüs ${ }^{1}$
}

Published online: 23 June 2021

๑) Springer Science+Business Media, LLC, part of Springer Nature 2021

\section{Retraction to: Biochemical Genetics (2017) 55:22-33 https://doi.org/ $10.1007 /$ s10528-016-9768-3}

The Editor-in-Chief and the publisher have retracted this article (Halász et al. 2017) because of irregularities during the peer review process. Therefore, the validity of the content of this article cannot be verified. Based on the results of a post-publication reviewing process, it was decided to allow the authors to resubmit a revision of their paper for evaluation. The revised version of this paper has been published and can be accessed at https://doi.org/10.1007/s10528-021-10090-7. Júlia Halász has stated on behalf of all co-authors that they agree to this retraction.

\section{Reference}

Halász J, Makovicz-Zsohár N, Szöke F et al (2017) Simple sequence repeat and S-locus genotyping to explore genetic variability in polyploidy Prunus spinosa and P. insititia. Biochem Genet. https://doi. org/10.1007/s10528-016-9768-3

Publisher's Note Springer Nature remains neutral with regard to jurisdictional claims in published maps and institutional affiliations.

The original article can be found online at https://doi.org/10.1007/s10528-016-9768-3.

Júlia Halász

genetics.prunus@gmail.com

1 Department of Genetics and Plant Breeding, Szent István University, Ménesi út 44., 1118 Budapest, Hungary

2 Lövőpetri, Hungary

3 Department of Horticulture, Faculty of Agriculture, Ataturk University, Erzurum, Turkey 